\title{
Risk Factors and Correlates of Neonatal Growth Velocity in Extremely Low Gestational Age Newborns. The ELGAN Study
}

\author{
Julie Bartholomew ${ }^{a} \quad$ Camilia R. Martin ${ }^{b} \quad$ Elizabeth Allred ${ }^{c}$ Minghua L. Chen ${ }^{a}$ \\ Richard A. Ehrenkranz ${ }^{e}$ Olaf Dammann ${ }^{a, d, f}$ Alan Leviton ${ }^{c}$ \\ ${ }^{a}$ Division of Newborn Medicine, Floating Hospital for Children at Tufts Medical Center, ${ }^{b}$ Department of \\ Neonatology Beth Israel Deaconess Medical Center, 'Neuroepidemiology Unit, Children's Hospital, dDepartment of \\ Public Health and Community Medicine, Tufts University School of Medicine, Boston, Mass., and ${ }^{\mathrm{e}}$ Division of \\ Perinatal Medicine, Department of Pediatrics, Yale University School of Medicine, New Haven, Conn., USA; \\ fPerinatal Neuroepidemiology Unit, Hannover Medical School, Hannover, Germany
}

\section{Key Words}

Premature infant $\cdot$ Nutrition $\cdot$ Growth velocity

\begin{abstract}
Objectives: To identify maternal and infant characteristics associated with reduced growth velocity (GV) in extremely premature newborns. Methods: We evaluated 1,187 infants born between 23 and 27 weeks' gestation at 14 institutions between 2002 and 2004 who survived until day 28 to identify the maternal and infant characteristics associated with a GV and caloric intake in the lowest quartile. Results: Newborns in the lowest gestational age and low birth weight categories, as well as those with intrauterine growth restriction, or high SNAP-II received relatively fewer $\mathrm{kcal} / \mathrm{kg} /$ day than their peers without these risk factors, but were not at increased risk of being in the lowest GV quartile. Newborns with bacteremia, patent ductus arteriosus, retinopathy of prematurity stage 3-5, or pulmonary illness received fewer calories, as did those who received medications or blood transfusions. However, in a multivariable model adjusting for confounders, only ventilator dependence on day 7 (OR $2.2,95 \% \mathrm{Cl} 1.5-3.2)$, early persistent pulmonary dysfunction (OR 1.8, 95\% Cl 1.3-2.5), and postnatal exposure to dexa-
\end{abstract}

methasone (OR 2.8, 95\% Cl 1.2-6.5) were associated with an increased risk of being in the lowest GV quartile. In this model, low caloric intake was not associated with low GV (OR 1.3, $95 \% \mathrm{Cl}$ 0.9-1.9). Conclusion: Variables associated with severe pulmonary disease convey more information about the risk of reduced GV during the first 28 postnatal days than does low caloric intake.

(c) 2013 S. Karger AG, Basel

\section{Introduction}

Many extremely preterm newborns are unable to maintain their birth weight centile at hospital discharge [1]. These infants are at greater risk of neurodevelopmental limitations than their peers who gained more weight [2-4].

Nutritional strategies such as the early introduction of parenteral and enteral feedings and maximizing protein and calorie intake are associated with improved weight gain [5-7]. Nevertheless, some extremely premature newborns do not gain weight as expected even when they receive nutrition within current guidelines [8]. Therefore, neonatal characteristics other than nutrition

\section{KARGER}

E-Mail karger@karger.com

www.karger.com/neo (c) 2013 S. Karger AG, Basel

1661-7800/13/1044-0298\$38.00/0
Olaf Dammann, MD

Department of Public Health and Community Medicine

Tufts University School of Medicine

136 Harrison Avenue, Boston, MA 02111 (USA)

E-Mail olaf.dammann@ tufts.edu 
are probably important correlates of postnatal weight gain. For example, neonatal illness and treatment-related factors might also contribute to suboptimal weight gain [9].

In this study, we wanted to evaluate to what extent peri- and neonatal characteristics are associated with reduced weight gain while adjusting for potential confounders including the provision of limited calorie intake.

\section{Methods}

\section{Sample}

The ELGAN (Extremely Low Gestational Age Newborn) Study [10] enrolled women who gave birth before 28 weeks gestation at one of 14 participating institutions. The 1,187 neonates who survived the first 28 postnatal days ( $79 \%$ of the 1,506 recruited infants) and for whom we could calculate growth velocity (GV) and caloric intake are the subjects of this study.

\section{Data Collection}

\section{Pregnancy Characteristics}

The clinical circumstances that led to preterm delivery were operationally defined using both data from the maternal interview and data abstracted from the medical record.

\section{Placenta Histology}

Briefly, infarcts and intervillous fibrin, fetal stem vessel thrombosis, and decidual hemorrhage, fibrin deposition consistent with abruption, syncytial knots and inflammation of the chorionic plate were coded as present or absent.

\section{Newborn Characteristics}

Gestational age estimates were based on the dates of embryo retrieval, intrauterine insemination, or fetal ultrasound before the 14 th week (62\%), followed by fetal ultrasound at 14 or more weeks (29\%), then last menstrual period without fetal ultrasound (7\%). Intrauterine growth restriction was defined as a birth weight $>2$ SDs below the expected mean of infants at the same GA in a referent sample [11]. We collected all the data for the first $12 \mathrm{~h}$ needed to calculate a SNAP-II ${ }^{\mathrm{TM}}$, a validated early illness severity and mortality risk score.

\section{Neonatal Morbidities and Treatment Variables}

We recorded the occurrence during the first 28 postnatal days of the following factors: duration of ventilator assistance, pneumothorax, pulmonary interstitial emphysema, pulmonary hemorrhage, early and late bacteremia, diagnosis and treatment of a patent ductus arteriosus (PDA), as well as the receipt of medications and blood products.

ELGANs were classified into three mutually exclusive early respiratory function groups: those with consistently low $\mathrm{FiO}_{2}$ (an $\mathrm{FiO}_{2}<0.23$ on all days between 3 and 7 days of life and receiving
$\mathrm{FiO}_{2} \leq 0.25$ on day 14 ), those with pulmonary deterioration (PD) (an $\mathrm{FiO}_{2}<0.23$ on any day between 3 and 7 days and receiving $\mathrm{FiO}_{2}$ $>0.25$ on day 14 ), and those with early and persistent pulmonary dysfunction (EPPD) (an $\mathrm{FiO}_{2} \geq 0.23$ on all days between 3 and 7 and receiving $\mathrm{FiO}_{2}>0.25$ on day 14) [12]. Chronic lung disease (CLD) was defined as receipt of supplemental oxygen at 36 weeks' post-menstrual age. Definitions of retinopathy of prematurity (ROP) characteristics were those of the International Committee for Classification of ROP [13].

\section{Growth Velocity}

Weights were recorded daily in the first postnatal week, then on days 14, 21 and 28. Because early weight gain is a function of birth weight [14], we chose a measure of GV that divided the daily weight gain by the initial weight. Because ELGANs lose weight during the first postnatal week, we began the GV interval on postnatal day 7 and defined GV as the difference between the day 28 and day 7 weights divided by the weight on day 7 , and then divided once again by 21 (the number of days between day 7 and day 28 ). This number is multiplied by 1,000 to express $\mathrm{GV}$ in $\mathrm{g} / \mathrm{kg} / \mathrm{day}$, so that: $\mathrm{GV}_{7-28}=1,000 \times\left[\left(\mathrm{wt}_{28}-\mathrm{wt}_{7}\right) / \mathrm{wt}_{7}\right] / 21$.

Newborns were separated into four quartiles of GV. The upper bound of the lowest GV quartile was $13.8 \mathrm{~g} / \mathrm{kg} /$ day, the median was $18.3 \mathrm{~g} / \mathrm{kg} / \mathrm{day}$, and the upper bound of the third quartile was $22.6 \mathrm{~g} / \mathrm{kg} /$ day.

\section{Nutritional Practices}

Detailed nutritional data collected daily for the first 7 postnatal days then weekly on days 14, 21 and 28 included concentrations, components, additives, and volumes of intravenous solutions, and enteral feedings. Macronutrient content was calculated by multiplying the daily total volume by the macronutrient content on the nutritional label for all formula types and nutritional additives. The specific figures for breast milk calculations were derived from the Ross Neonova system, version 4.5, 1999 (compiled from 'composition of mature and preterm human milk based on values obtained in the literature', Ross Medical Dept.). We used the values for mature milk, since the composition for preterm milk only lasts for approximately 14 postnatal days.

Total kilocalories per day were divided by the birth weight until the birth weight was surpassed, then by the weight on the day the nutritional information was collected. Macronutrient intake was calculated as the mean total $\mathrm{kcal} / \mathrm{kg} /$ day for 28 days from both parenteral and enteral routes and each newborn was allocated to one of four quartiles of caloric intake based on the calculated mean calorie intake [8].

\section{Statistical Analyses}

We evaluated the following two hypotheses, expressed in their null form: (1) ante-, peri- and postnatal characteristics of the newborn are not associated with GV between days 7 and 28 and (2) neonates in the lowest quartile of calories received (per $\mathrm{kg} / \mathrm{day}$ ) have the same risk of being in the lowest quartile for GV regardless of ante-, peri- and postnatal characteristics as their peers who received more calories.

Among newborns with specific pre-, peri-, and neonatal characteristics, we calculated the percentage who received a mean of total $\mathrm{kcal} / \mathrm{kg} /$ day that was in the lowest quartile, as well as the percent who had a GV in the lowest quartile. If these characteristics were not associated with nutritional intake or GV, one would ex- 
Table 1. Percent of infants with the delivery characteristics listed on the left who also were in the lowest quartile of mean total calories ( $\mathrm{kcal} / \mathrm{kg} /$ day) and in the lowest quartile of GV (row percents)

\begin{tabular}{|c|c|c|c|c|}
\hline \multicolumn{2}{|c|}{ Delivery characteristics } & \multicolumn{2}{|c|}{ Lowest quartile } & \multirow[t]{2}{*}{$\mathrm{n}$} \\
\hline & & $\begin{array}{l}\text { total } \\
\text { calories }^{\dagger}\end{array}$ & $\begin{array}{l}\text { growth } \\
\text { velocity }\end{array}$ & \\
\hline \multirow{3}{*}{$\begin{array}{l}\text { Antenatal } \\
\text { steroid } \\
\text { course }\end{array}$} & complete & 24 & 25 & 751 \\
\hline & partial & 24 & 26 & 309 \\
\hline & none & 30 & 23 & 123 \\
\hline \multirow{5}{*}{$\begin{array}{l}\text { Pregnancy } \\
\text { complication }\end{array}$} & preterm labor & 25 & 26 & 530 \\
\hline & pPROM* & 24 & 22 & 255 \\
\hline & preeclampsia & 26 & 25 & 154 \\
\hline & abruption & 21 & 30 & 125 \\
\hline & cervical insufficiency & 22 & 22 & 73 \\
\hline \multirow{3}{*}{$\begin{array}{l}\text { Duration } \\
\text { of labor }\end{array}$} & $0 \mathrm{~h}$ & 24 & 21 & 295 \\
\hline & $>0$ to $\leq 12 \mathrm{~h}$ & 21 & 25 & 263 \\
\hline & $>12 \mathrm{~h}$ & 27 & 27 & 629 \\
\hline \multirow{3}{*}{$\begin{array}{l}\text { Duration } \\
\text { of ruptured } \\
\text { membranes }\end{array}$} & $<1 \mathrm{~h}$ & 25 & 25 & 698 \\
\hline & 1 to $24 \mathrm{~h}$ & 23 & 25 & 194 \\
\hline & $>24 \mathrm{~h}$ & 24 & 24 & 295 \\
\hline \multirow[t]{3}{*}{ Magnesium } & none & 26 & 21 & 379 \\
\hline & tocolysis & 24 & 27 & 648 \\
\hline & seizure prophylaxis & 23 & 26 & 149 \\
\hline \multirow{2}{*}{$\begin{array}{l}\text { Cesarean } \\
\text { delivery }\end{array}$} & yes & 24 & 24 & 789 \\
\hline & no & 27 & 27 & 398 \\
\hline \multirow[t]{2}{*}{ Fever** } & yes & 34 & 39 & 76 \\
\hline & no & 24 & 24 & 1,068 \\
\hline
\end{tabular}

${ }^{\dagger}$ Mean of total calories $(\mathrm{kcal} / \mathrm{kg} / \mathrm{day})$ on days 7, 14, 21, and 28 .

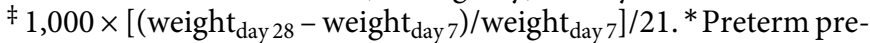
mature rupture of membranes. ${ }^{* *}$ From before delivery to $48 \mathrm{~h}$ after delivery.

pect $25 \%$ of neonates with each characteristic to have a nutritional intake or GV in the lowest quartile.

Characteristics associated with an over-representation of neonates in the lowest quartile for GV ( $>35 \%$ where $25 \%$ is expected) were entered into multivariable logistic regression models that adjusted for all potential confounders including a hospital stratum variable, and estimated the contribution of limited caloric intake, ante-, peri-, and postnatal characteristics to limited GV. In particular, we created two multivariable logistic regression models of the risk of a GV in the lowest quartile. The first contained only two gestational age categories (i.e. 23-24 and 25-26 weeks), a hospital stratum variable, and a variable for caloric intake in the lowest quartile. The second included these variables plus intercurrent illnesses and their correlates (mechanical ventilation on day 7 , EPPD, pneumothorax, pulmonary interstitial emphysema, postnatal receipt of dexamethasone, as well as a sedative). We present the contributions as odds ratios (OR) with $95 \%$ confidence intervals $(\mathrm{CI})$.
Table 2. Percent of infants with the characteristics listed on the left who were also in the lowest quartile of mean total calories ( $\mathrm{kcal} / \mathrm{kg} /$ day) and in the lowest quartile of GV among infants (row percents)

\begin{tabular}{|c|c|c|c|c|}
\hline \multicolumn{2}{|c|}{ Characteristics of the infant } & \multicolumn{2}{|c|}{ Lowest quartile } & \multirow[t]{2}{*}{$\mathrm{n}$} \\
\hline & & $\begin{array}{l}\text { total } \\
\text { calories }\end{array}$ & $\begin{array}{l}\text { growth } \\
\text { velocity }\end{array}$ & \\
\hline \multirow[t]{2}{*}{ Sex } & male & 26 & 25 & 624 \\
\hline & female & 27 & 25 & 563 \\
\hline \multirow[t]{2}{*}{ Type of gestation } & singleton & 24 & 26 & 798 \\
\hline & multiple & 25 & 23 & 389 \\
\hline \multirow{3}{*}{$\begin{array}{l}\text { Gestational age, } \\
\text { weeks }\end{array}$} & $23-24$ & 43 & 29 & 249 \\
\hline & $25-26$ & 25 & 26 & 551 \\
\hline & 27 & 13 & 21 & 387 \\
\hline \multirow[t]{3}{*}{ Birth weight, g* } & $\leq 750$ & 37 & 26 & 443 \\
\hline & $751-1,000$ & 20 & 26 & 517 \\
\hline & $>1,000$ & 10 & 20 & 227 \\
\hline \multirow[t]{3}{*}{ BW Z-score** } & $<-2$ & 34 & 23 & 65 \\
\hline & $\geq-2,<-1$ & 28 & 20 & 154 \\
\hline & $\geq-1$ & 23 & 26 & 968 \\
\hline \multirow[t]{3}{*}{ SNAP-II ${ }^{\mathrm{TM} * * *}$} & $<20$ & 19 & 22 & 609 \\
\hline & $20-29$ & 28 & 27 & 298 \\
\hline & $30+$ & 35 & 30 & 260 \\
\hline
\end{tabular}

${ }^{\dagger}$ Mean of total calories (kcal/kg/day) on days 7, 14, 21, and 28. ${ }^{\ddagger} 1,000 \times\left[\left(\right.\right.$ weight $_{\text {day } 28}-$ weight $\left._{\text {day } 7}\right) /$ weight $\left._{\text {day }}\right] / 21{ }^{*}$ Birth weight. ** Yudkin et al. standard [11]. ${ }^{* * *}$ Score of Neonatal Acute Physiology II [13].

\section{Results}

\section{Delivery Characteristics (table 1)}

Among all delivery characteristics, only maternal fever was associated with a slightly elevated risk of being in the lowest quartiles of nutrition and GV.

\section{Placenta Characteristics}

The percentage of newborns with caloric intake and GV values in the lowest quartile was not over- or under-represented among infants with any of the histologic placenta characteristics we studied (data not shown).

\section{Neonatal Characteristics (table 2)}

The percentage of infants whose caloric intake put them in the lowest quartile decreased with increasing gestational age, birth weight, and birth weight Z-score, while it increased with increasing SNAP-IITM. The percentage 
Table 3. Percent of infants with the diagnostic and classification entity listed on the left who were also in the lowest quartile of mean total calories ( $\mathrm{kcal} / \mathrm{kg} / \mathrm{day}$ ) and in the lowest quartile of GV (row percents)

\begin{tabular}{|c|c|c|c|c|}
\hline \multirow{2}{*}{$\begin{array}{l}\text { Diagnostic and } \\
\text { classification entities }\end{array}$} & & \multicolumn{2}{|c|}{ Lowest quartile } & \multirow[t]{2}{*}{$\mathrm{n}$} \\
\hline & & total & growth & \\
\hline \multirow[t]{2}{*}{ Bacteremia, week 1} & yes & 43 & 27 & 75 \\
\hline & no & 23 & 25 & 1,112 \\
\hline \multirow{2}{*}{$\begin{array}{l}\text { Bacteremia, } \\
\text { weeks 2-4 }\end{array}$} & yes & 39 & 25 & 300 \\
\hline & no & 20 & 25 & 886 \\
\hline \multirow[t]{3}{*}{ PDA } & echo & 32 & 26 & 624 \\
\hline & clinical & 22 & 25 & 163 \\
\hline & none & 14 & 23 & 400 \\
\hline \multirow[t]{2}{*}{ Pneumothorax } & yes & 49 & 33 & 87 \\
\hline & no & 23 & 24 & 1,100 \\
\hline \multirow{2}{*}{$\begin{array}{l}\text { Pulmonary } \\
\text { interstitial } \\
\text { emphysema }\end{array}$} & yes & 42 & 37 & 186 \\
\hline & no & 21 & 23 & 1,001 \\
\hline \multirow{2}{*}{$\begin{array}{l}\text { Pulmonary } \\
\text { hemorrhage }\end{array}$} & yes & 42 & 37 & 43 \\
\hline & no & 24 & 24 & 1,144 \\
\hline \multirow{3}{*}{$\begin{array}{l}\text { Respiratory } \\
\text { group } \\
\text { classification }\end{array}$} & EPPD & 31 & 34 & 485 \\
\hline & $\mathrm{PD}$ & 24 & 18 & 437 \\
\hline & low $\mathrm{FiO}_{2}$ & 9 & 17 & 235 \\
\hline \multirow[t]{3}{*}{ CLD } & vent and $\mathrm{O}_{2}$ & 40 & 26 & 105 \\
\hline & $\mathrm{O}_{2}$ only & 29 & 26 & 505 \\
\hline & no CLD & 18 & 24 & 571 \\
\hline \multirow{4}{*}{$\begin{array}{l}\text { Retinopathy of } \\
\text { prematurity } \\
\text { (stage) }\end{array}$} & none & 16 & 17 & 304 \\
\hline & 1 & 14 & 25 & 260 \\
\hline & 2 & 27 & 24 & 271 \\
\hline & $3-5$ & 38 & 32 & 345 \\
\hline
\end{tabular}

${ }^{\dagger}$ Mean of total calories (kcal/kg/day) on days 7, 14, 21, and 28. $\neq 1,000 \times\left[\left(\right.\right.$ weight $_{\text {day } 28}-$ weight $\left._{\text {day } 7}\right) /$ weight $\left._{\text {day }} 7\right] / 21$.

of infants with GV values in the lowest quartile decreased with increasing gestational age, and increased with increasing SNAP-II ${ }^{\mathrm{TM}}$.

\section{Prematurity-Related Illness (table 3)}

Neonatal bacteremia, PDA, respiratory illness, and severe $\mathrm{ROP}$ were associated with a larger than expected percentage of infants whose caloric intake was in the lowest quartile. Infants with severe ROP and severe respiratory illness had an increased likelihood of being in the lowest GV quartile.

Risk Factors and Correlates of Neonatal Growth Velocity in ELGANs
Table 4. Percent of infants with the ventilation characteristics listed on the left who were in the lowest quartile of mean total calories (kcal/kg/day) and in the lowest quartile of GV (row percents)

\begin{tabular}{|c|c|c|c|c|}
\hline \multirow[t]{2}{*}{ Time } & \multirow{2}{*}{$\begin{array}{l}\text { Mechanical or } \\
\text { high-frequency } \\
\text { ventilation }\end{array}$} & \multicolumn{2}{|c|}{ Lowest quartile } & \multirow[t]{2}{*}{$\mathrm{n}$} \\
\hline & & $\begin{array}{l}\text { total } \\
\text { calories }\end{array}$ & $\begin{array}{l}\text { growth } \\
\text { velocity }\end{array}$ & \\
\hline \multirow[t]{2}{*}{ Day 1} & yes & 25 & 26 & 1,104 \\
\hline & no & 16 & 6 & 83 \\
\hline \multirow[t]{2}{*}{ Day 7} & yes & 34 & 32 & 715 \\
\hline & no & 10 & 14 & 471 \\
\hline \multirow[t]{2}{*}{ Day 14} & yes & 34 & 30 & 701 \\
\hline & no & 11 & 18 & 485 \\
\hline \multirow[t]{2}{*}{ Day 21} & yes & 37 & 27 & 679 \\
\hline & no & 8 & 22 & 506 \\
\hline \multirow[t]{2}{*}{ Day 28} & yes & 41 & 27 & 575 \\
\hline & no & 10 & 23 & 607 \\
\hline 36 weeks & yes & 40 & 28 & 105 \\
\hline PMA* & no & 23 & 25 & 1,076 \\
\hline
\end{tabular}

* Postmenstrual age. ${ }^{\dagger}$ Mean of total calories (kcal/kg/day) on days $7,14,21$, and $28 .{ }^{\ddagger} 1,000 \times\left[\left(\right.\right.$ weight $_{\text {day } 28}-$ weight $\left._{\text {day } 7}\right) /$ weight $\left._{\text {day }}\right] / 21$.

\section{Ventilation Assistance (table 4)}

In light of the associations between severe respiratory illness and low GV, we explored the issue of respiratory care a bit more closely and tabulated infants classified by whether or not they received mechanical or highfrequency ventilation assistance on selected days. While the caloric intake gap between groups widened over the first 4 postnatal weeks, the GV gap tended to become smaller.

Medications and Therapies (table 5)

Almost all pharmacological interventions were associated with an increased risk for being in the lowest quartile of caloric intake, except for methylxanthine exposure, which was associated with a decreased risk. Infants who received dexamethasone were most likely to be in the lowest GV quartile.

\section{Multivariable Analysis (table 6)}

In the logistic regression model limited to gestational age categories and a variable for caloric intake in the lowest quartile, only the lowest quartile calories variable was statistically significant (OR 1.5, 95\% CI 1.1-2.1). In the 
Table 5. Percent of infants with the intervention characteristics listed on the left who were in the lowest quartile of mean total calories ( $\mathrm{kcal} / \mathrm{kg} /$ day) and in the lowest quartile of GV (row percents)

\begin{tabular}{|c|c|c|c|c|}
\hline \multicolumn{2}{|c|}{ Medications and therapies } & \multicolumn{2}{|c|}{ Lowest quartile } & \multirow[t]{2}{*}{$\mathrm{n}$} \\
\hline & & $\begin{array}{l}\text { total } \\
\text { calories }\end{array}$ & $\begin{array}{l}\text { growth } \\
\text { velocity }^{\ddagger}\end{array}$ & \\
\hline \multirow{2}{*}{$\begin{array}{l}\text { Surfactant } \\
\text { (first week) }\end{array}$} & yes & 26 & 26 & 1,068 \\
\hline & no & 16 & 12 & 119 \\
\hline \multirow{2}{*}{$\begin{array}{l}\text { Methylxanthine } \\
\quad(15+\text { days })\end{array}$} & yes & 16 & 22 & 727 \\
\hline & no & 40 & 30 & 460 \\
\hline \multirow{2}{*}{$\begin{array}{l}\text { Hydrocortisone } \\
\quad \text { (first } 2 \text { weeks) }\end{array}$} & yes & 47 & 31 & 127 \\
\hline & no & 22 & 24 & 1,060 \\
\hline \multirow{2}{*}{$\begin{array}{l}\text { Dexamethasone } \\
\text { (first } 2 \text { weeks) }\end{array}$} & yes & 43 & 57 & 28 \\
\hline & no & 24 & 24 & 1,159 \\
\hline \multirow{2}{*}{$\begin{array}{l}\text { Analgesics } \\
\quad \text { (first } 4 \text { weeks) }\end{array}$} & yes & 32 & 28 & 813 \\
\hline & no & 9 & 18 & 374 \\
\hline \multirow{2}{*}{$\begin{array}{l}\text { Sedative } \\
\quad \text { (first } 4 \text { weeks) }\end{array}$} & yes & 46 & 33 & 313 \\
\hline & no & 17 & 22 & 874 \\
\hline \multirow{2}{*}{$\begin{array}{l}\text { PDA treatment* } \\
\quad \text { (first } 4 \text { weeks) }\end{array}$} & yes & 32 & 29 & 729 \\
\hline & no & 13 & 19 & 458 \\
\hline \multirow{2}{*}{$\begin{array}{l}\text { Transfusion } \\
\quad \text { (in 3-4 weeks) }\end{array}$} & yes & 36 & 27 & 681 \\
\hline & no & 6 & 22 & 506 \\
\hline
\end{tabular}

${ }^{\dagger}$ Mean of total calories (kcal/kg/day) on days 7, 14, 21, and 28. ${ }^{\ddagger} 1,000 \times\left[\left(\right.\right.$ weight $_{\text {day } 28}-$ weight $\left._{\text {day } 7}\right) /$ weight $\left._{\text {day } 7}\right] / 21$. ${ }^{*}$ Among those with a clinical or echo PDA diagnosis. ${ }^{\S}$ Packed cells or whole blood.

model that also included indicators of postnatal illnesses, low caloric intake during the first 28 postnatal days was no longer associated with a $\mathrm{GV}$ in the lowest quartile (OR 1.3, 95\% CI 0.9-1.9). Infants dependent on ventilator support on postnatal day 7 (OR 2.2, 95\% CI 1.5-3.2), those who had EPPD (OR 1.8, 95\% CI 1.3-2.5), and those exposed to postnatal dexamethasone (OR 2.8, 95\% CI 1.2-6.5) had an increased risk of being in the lowest GV quartile.

\section{Discussion}

The first of our major findings is that indicators of breathing difficulties, including ventilator dependence on postnatal day 7, EPPD, and receipt of dexamethasone were each associated with low GV during weeks 2-4. The second major finding is that low GV during that time interval was not associated with caloric intake in the lowest quartile.

\section{Dexamethasone}

The relationship between dexamethasone and poor $\mathrm{GV}$ is controversial $[15,16]$. Because the use of dexamethasone must be viewed as an indicator of the severity
Table 6. ORs and $95 \%$ CIs that variables listed on the left are associated with a GV in the lowest quartile. Estimates are adjusted for the other variables in this table. Estimates are adjusted for the other variables in each of the two logistic regression models. The top model does not include any intercurrent illness, while the bottom model does

\begin{tabular}{ll}
\hline & ORs (95\% CI) \\
\hline Without any intercurrent illness & \\
Gestational age: $23-24$ weeks & $1.2(0.8-1.9)$ \\
Gestational age: $25-26$ weeks & $1.2(0.8-1.7)$ \\
Calories in lowest quartile & $\mathbf{1 . 5}(\mathbf{1 . 1}-\mathbf{2 . 1})$ \\
\hline With intercurrent illnesses & \\
Gestational age: $23-24$ weeks & $0.8(0.5-1.3)$ \\
Gestational age: $25-26$ weeks & $1.0(0.7-1.4)$ \\
Mechanical or high-frequency & \\
$\quad$ ventilation on day 7 & $\mathbf{2 . 2 ( 1 . 5 - 3 . 2 )}$ \\
EPPD & $\mathbf{1 . 8}(\mathbf{1 . 3}-\mathbf{2 . 5})$ \\
Dexamethasone & $\mathbf{2 . 8}(\mathbf{1 . 2}-\mathbf{6 . 5})$ \\
Sedative & $0.9(0.6-1.3)$ \\
Pneumothorax & $0.9(0.5-1.5)$ \\
Pulmonary interstitial emphysema & $1.3(0.9-1.9)$ \\
Calories in lowest quartile & $1.3(0.9-1.9)$ \\
\hline
\end{tabular}

Statistically significant ORs are bold type $(\mathrm{p}<0.05)$.

of respiratory dysfunction, the administration of dexamethasone might be an example of confounding by indication [17].

\section{Respiratory Illness}

Only one other study found that ventilator-dependent newborns are at increased risk of poor GV [9]. One explanation for a link between ventilation and limited growth invokes systemic inflammation. Mechanically ventilated human newborns [18, 19], adult mice [20] and fetal sheep [21] are more likely than their non-ventilated peers to have systemic inflammation. Another explanation invokes oxidative stress, which is accompanied by systemic inflammation [22].

Ventilator dependence on day 7, but not on days 1,14 or 28, predicted low GV during weeks 2-4 of life. A likely explanation is that each day of ventilator dependence competes in the multivariable model with each of the other days of ventilator dependence.

\section{Caloric Intake}

Neonates who received the lowest amount of calories were not at increased risk of having the most limited weight gain when the multivariable logistic regres- 
sion model contained indicators of respiratory dysfunction. This finding leads to the inference that low caloric intake contributes less information about the risk of low weight gain than do indicators of illness severity.

We offer three explanations. First, the sickest newborns are most likely to be fluid overloaded [23]. Second, perhaps total calories are less important than the sources of the calories [8]. Third, their illnesses might limit the absorption and/or utilization of the kilocalories delivered [24].

\section{Modifiable Exposures}

Our goal was to find modifiable early risk factors and correlates of poor GV so that newborns with these characteristics would be considered a potential target population for interventions. Of the three characteristics, we identified only dexamethasone exposure can be eliminated easily. Avoiding exposure to mechanical ventilation is possible [25] but difficult, while EPPD is unlikely to be avoided anytime soon.

Our study has several strengths including a large sample size, selection of infants based on gestational age and not birth weight [26], and prospective data collection. Our limitations include an inability to distinguish between causation and association that the sickest infants were more likely to be treated aggressively than others who were not quite so sick, making our study prone to confounding by indication [17], and reliance on GV as a measure of adequate nutrition. Ideally, more precise measures of nutrition are needed.

\section{Conclusions}

Among ELGANs, indicators of early pulmonary illness severity, including receipt of dexamethasone, but not low caloric intake, are associated with an increased risk for GV below the 25 th percentile during postnatal weeks $2-4$.

\section{Acknowledgements}

This study was supported by NIH (5U01NS040069-05 and P30-HD-18655). The authors gratefully acknowledge the contributions of their subjects and their families, as well as those of their colleagues, who are identified below: Bhavesh Shah, Karen Christianson, Colleen Hallisey, Caitlin Hurley, Miren Creixell, Linda J. Van Marter, Kathleen Lee, Anne McGovern, Jill Gambardella, Susan Ursprung, Ruth Blomquist, Robert Insoft, Jennifer G. Wilson, Maureen Pimental, Cynthia Cole, John Fiascone, Janet Madden, Ellen Nylen, Anne Furey, Francis Bednarek, Mary Naples, Beth Powers, Joanne Williams, Elaine Romano, T. Michael O'Shea, Debbie Gordon, Teresa Harold, Gail Hounsell, Debbie Hiatt, Stephen Engelke, Sherry Moseley, Linda Pare, Donna Smart, Joan Wilson, Carl Bose, Gennie Bose, Janice Wereszczak, Mariel Portenga, Dinah Sutton, Padmani Karna, Carolyn Solomon, Michael D. Schreiber, Grace Yoon, Daniel Batton, and Beth Kring.

\section{References}

1 Ehrenkranz RA, Younes N, Lemons JA, et al: Longitudinal growth of hospitalized very low birth weight infants. Pediatrics 1999;104:280289.

2 Latal-Hajnal B, von Siebenthal K, Kovari H, Bucher HU, Largo RH: Postnatal growth in VLBW infants: significant association with neurodevelopmental outcome. J Pediatr 2003; 143:163-170.

-3 Ehrenkranz RA, Dusick AM, Vohr BR, Wright LL, Wrage LA, Poole WK: Growth in the neonatal intensive care unit influences neurodevelopmental and growth outcomes of extremely low birth weight infants. Pediatrics 2006;117:1253-1261.

4 Casey PH, Whiteside-Mansell L, Barrett K, Bradley RH, Gargus R: Impact of prenatal and/or postnatal growth problems in low birth weight preterm infants on school-age outcomes: an 8-year longitudinal evaluation. Pediatrics 2006;118:10781086.
5 Olsen IE, Richardson DK, Schmid CH, Ausman LM, Dwyer JT: Intersite differences in weight growth velocity of extremely premature infants. Pediatrics 2002;110:1125-1132.

-6 Wilson DC, Cairns P, Halliday HL, Reid M, McClure G, Dodge JA: Randomised controlled trial of an aggressive nutritional regimen in sick very low birthweight infants. Arch Dis Child Fetal Neonatal Ed 1997; 77:F4-F11.

7 Pointdexter B: Early provision of parenteral amino acids in extremely low birth weight infants: relation to growth and neurodevelopmental outcomes. J Pediatr 2006; 148:6.

-8 Martin CR, Brown YF, Ehrenkranz RA, et al: Nutritional practices and growth velocity in the first month of life in extremely premature infants. Pediatrics 2009;124:649-657.

$\checkmark 9$ Loui A, Tsalikaki E, Maier K, Walch E, Kamarianakis $\mathrm{Y}$, Obladen M: Growth in high risk infants $<1,500 \mathrm{~g}$ birthweight during the first 5 weeks. Early Hum Dev 2008;84:645650 .
10 O'Shea TM, Allred EN, Dammann O, et al: The ELGAN Study of the brain and related disorders in extremely low gestational age newborns. Early Hum Dev 2009;85:719-725.

11 Yudkin PL, Aboualfa M, Eyre JA, Redman CW, Wilkinson AR: New birthweight and head circumference centiles for gestational ages 24 to 42 weeks. Early Hum Dev 1987; 15: $45-52$.

12 Laughon M, Allred EN, Bose C, et al: Patterns of respiratory disease during the first 2 postnatal weeks in extremely premature infants. Pediatrics 2009;123:1124-1131.

$\checkmark 13$ The Committee for the Classification of Retinopathy of Prematurity: An international classification of retinopathy of prematurity. Arch Ophthalmol 1984;102:11301134.

14 Bloom BT, Mulligan J, Arnold C, et al: Improving growth of very low birth weight infants in the first 28 days. Pediatrics 2003;112: 8-14. 
15 Gibson AT, Pearse RG, Wales JK: Growth retardation after dexamethasone administration: assessment by knemometry. Arch Dis Child 1993;69:505-509.

16 Doyle LW, Ehrenkranz RA, Halliday HL: Dexamethasone treatment after the first week of life for bronchopulmonary dysplasia in preterm infants: a systematic review. Neonatology 2010;98:289-296.

17 Bosco JL, Silliman RA, Thwin SS, et al: A most stubborn bias: no adjustment method fully resolves confounding by indication in observational studies. J Clin Epidemiol 2010;63:64-74.

18 Bohrer B, Silveira RC, Neto EC, Procianoy RS: Mechanical ventilation of newborns infant changes in plasma pro- and anti-inflammatory cytokines. J Pediatr 2010;156:16-19.
19 Bose CL, Laughon MM, Allred EN, et al: Systemic inflammation associated with mechanical ventilation among extremely preterm infants. Cytokine 2013;61:315-322.

20 Walker MG, Yao LJ, Patterson EK, et al: The effect of tidal volume on systemic inflammation in acid-induced lung injury. Respiration 2011;81:333-342.

21 Hillman NH, Polglase GR, Pillow JJ, Saito M, Kallapur SG, Jobe AH: Inflammation and lung maturation from stretch injury in preterm fetal sheep. Am J Physiol Lung Cell Mol Physiol 2011;300:L232-L241.

22 Vento M, Moro M, Escrig R, et al: Preterm resuscitation with low oxygen causes less oxidative stress, inflammation, and chronic lung disease. Pediatrics 2009;124:e439-e449.
23 Oh W: Renal function and fluid therapy in high risk infants. Biol Neonate 1988;53:230236.

24 Shields B, Wacogne I, Wright CM: Weight faltering and failure to thrive in infancy and early childhood. BMJ 2012;345:e5931.

25 Gopel W, Kribs A, Ziegler A, et al: Avoidance of mechanical ventilation by surfactant treatment of spontaneously breathing preterm infants (AMV): an open-label, randomised, controlled trial. Lancet 2011;378: 1627-1634.

26 Arnold CC, Kramer MS, Hobbs CA, McLean $\mathrm{FH}$, Usher RH: Very low birth weight: a problematic cohort for epidemiologic studies of very small or immature neonates. Am J Epidemiol 1991;134:604-613. 